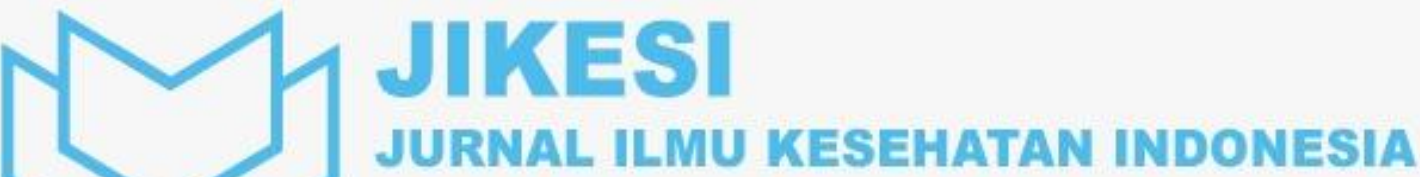 \\ (Indonesian Journal of Health Science)
}

Artikel Penelitian

\section{Karakteristik Endometriosis di RSUP Dr. M. Djamil Padang Periode} 2017- 2019

\author{
Nurul Ufa Tifani ${ }^{1}$, Dedy Hendry ${ }^{2}$, Yose Ramda Ilhami ${ }^{3}$ \\ ${ }^{1}$ Program Studi Profesi Dokter Fakultas Kedokteran Universitas Andalas, Padang \\ ${ }^{2}$ Bagian IImu Obstetri dan Ginekologi Fakultas Kedokteran Universitas Andalas/RSUP Dr. M. Djamil Padang \\ ${ }^{3}$ Bagian IImu Kardiologi dan Kedokteran Vaskuler Fakultas Kedokteran Universitas Andalas Padang/RSUP Dr. M. Djamil Padang
}

\section{A B S T R A C T}

Latar Belakang. Endometriosis adalah salah satu penyakit ginekologi jinak yang paling umum, penyakit ini dikaitkan dengan nyeri panggul dan subfertilitas pada sekitar 176 juta wanita diseluruh dunia. Keterlambatan pemeriksaan penyakit ini dapat terjadi selama bertahun-tahun karena diagnosis penyakit ini harus melalui laparoskopi.

Objektif. Mengetahui gambaran karakteristik endometriosis di RSUP Dr. M. Djamil Padang periode 2017-2019.

Metode. Penelitian ini bersifat deskriptif dengan 98 orang penderita endometriosis di RSUP Dr. M. Djamil Padang pada tahun 2017- 2019 sebagai sampel penelitian. Instrumen dari penelitian ini adalah data rekam medik dan hasil wawancara dengan pasien yang telah memberikan persetujuan dengan informed consent.

Hasil. Kasus endometriosis paling banyak ditemukankan pada kelompok usia reproduktif $(85,71 \%)$, nullipara $(60,20 \%)$, kategori IMT berat badan normal $(35,71 \%)$, lama infertilitas $\geq 5$ tahun (27,55\%), dengan keluhan utama berupa dismenorea (69,39\%). Stadium penyakit yang paling banyak di temukan adalah stadium III-IV $(82,65 \%)$, pada lokasi anatomis internal pelvis, mayoritas pasien diberikan terapi hormon selama 3 bulan setelah terapi (75,51\%), merasakan perbaikan rasa nyeri $(83,67 \%)$, tidak melakukan program kehamilan (92,86\%), dan tidak mengalami kekambuhan setelah terapi $(88,78 \%)$.

Kesimpulan. Kejadian endometriosis tinggi pada wanita usia reproduktif, pemberian edukasi mengenai endometriosis yang baik perlu dilakukan agar dapat mengurangi penundaan diagnosis penyakit ini sehingga bisa ditangani ketika stadium ringan.

Kata kunci: endometriosis, karakteristik.

Background Endometriosis is one of the most common benign gynecological diseases, this disease is associated with pelvic pain and subfertility in approximately 176 million women worldwide. Delay in the examination of this disease can occur for years because the diagnosis of this disease must go through laparoscopy.

Objective. This research was conducted to find out the characteristics of endometriosis in RSUP Dr. M. Djamil Padang

for the period of 2017-2019.

Methods. This research is a descriptive study with 98 patients diagnosed with endometriosis in RSUP Dr. M. Djamil Padang in 2017 - 2019 as the research sample. The instruments of this study were medical record data and results of interviews with patients who had given their approval with informed consent.

Results. The cases of endometriosis were commonly found in the reproductive age group (85.71\%), nulliparous (60.20\%), normal weight BMI category (35.71\%), duration of infertility $\geq 5$ years (27.55\%), with the chief complaint of dysmenorrhoea (69.39\%). The most common stages of disease were found to be stage III-IV (82.65\%), on internal pelvic anatomic location, the majority of patients were given hormone therapy for 3 months after therapy (75.51\%), felt pain improvement (83.67\%), did not carry out a pregnancy program (92.86\%), and did not experience a recurrence after therapy (88.78\%).

Conclusion. This study concludes that the incidence of endometriosis is high in women of reproductive age. Providing good education about endometriosis is important in order to reduce the delay in diagnosis of this disease so that it can be treated when the stadium was still mild.

Keyword: characteristic, endometriosis,

\section{Apa yang sudah diketahui tentang topik ini?}

Endometriosis adalah penyakit ginekologi jinak yang paling banyak ditemukan pada wanita usia subur. 
Apa yang ditambahkan pada studi ini?

Stadium endometriosis yang paling banyak ditemukan di RSUP Dr. M. Djamil Padang adalah stadium III-IV dengan mayoritas pasien mendapatkan terapi hormon berupa GNRH Agonis selama 3 bulan pos-terapi, merasakan perbaikan rasa nyeri, tidak melakukan program kehamilan, dan tidak mengalami kekambuhan.

\section{Pendahuluan}

Endometriosis adalah penyakit kronik yang dikaitkan dengan nyeri panggul dan subfertilitas pada \pm 176 juta wanita di seluruh dunia. Penyakit ini sering mengalami keterlambatan diagnosis sehingga menyebabkan gangguan pada kualitas hidup penderita secara signifikan. ${ }^{1}$

Endometriosis merupakan salah satu penyakit ginekologi jinak yang paling umum. Penyakit ini terjadi pada 6-10\% perempuan dalam masa subur, namun angka kejadian secara pasti tidak diketahui karena diagnosis pada penyakit ini harus melalui laparoskopi yang menyebabkan keterlambatan diagnosis selama bertahun-tahun. Sebanyak 50-60\% perempuan yang menderita nyeri panggul dan $50 \%$ wanita yang mengalami infertilitas menderita endometriosis. Sekitar $2 / 3$ perempuan dewasa dengan nyeri panggul asiklik kronik ditemukan endometriosis dari laparoskopi. ${ }^{2}$

Penelitian yang telah dilakukan di RSUP Dr. M. Djamil Padang mendapatkan 46,1\% pasien datang dengan infertilitas sebagai keluhan utama dan $61,7 \%$ pasien belum pernah hamil atau melahirkan. $^{3}$

Faktor proteksi untuk penyakit ini adalah multiparitas, menyusui, meningkatnya rasio pinggal-panggul, olahraga, dan konsumsi buah serta sayuran. ${ }^{4}$

Etiologi penyakit ini bersifat multifaktorial seperti komponen hormon, sistem imun, dan genetic. Hubungan estrogen dengan endometriosis sangat erat berkaitan, dan 2/3 perempuan yang didiagnosis dengan penyakit ini juga memiliki anggota keluarga yang mengalami endometriosis. Beberapa teori bagaimana endometriosis dapat terjadi yang telah diterima secara luas adalah teori menstruasi retrograde dan teori coelomic metaplasia. Semua teori yang dikemukakan bersifat komplemen terhadap teori lainnya. Gejala dan pertanda endometriosis adalah nyeri haid (dismenorea), nyeri saat berhubungan intim (dispareunia), nyeri saat buang air kecil
CORRESPONDING AUTHOR

Phone: +6282386738463

E-mail: nurululfatifani@gmail.com

ARTICLE INFORMATION

Received: August $3^{\text {rd }}$, 2020

Revised: April 18 ${ }^{\text {th }}, 2021$

Available online: May $27^{\text {th }}, 2021$

(disuria), nyeri saat buang air besar (dyschezia), ketidaknyamanan pada perut dan pinggang bawah, serta nyeri panggul kronik (bersifat non siklik dan berlangsung setidaknya selama 6 bulan). Selain itu, banyak perempuan yang menderita endometriosis tanpa menunjukan gejala seperti diatas (asymptomatic) dan ditemukan lesi secara tidak sengaja saat operasi. ${ }^{5}$

Penelitian terkait gambaran kejadian endometriosis di Indonesia masih sedikit dilakukan di Indonesia salah satunya di Provinsi Sumatera Barat, dan RSUP Dr. M. Djamil Padang merupakan Rumah Sakit rujukan utama di Sumatera Barat. Oleh karena itu, peneliti tertarik untuk melakukan penelitian mengenai gambaran karakteristik endometriosis di RSUP Dr. M. Djamil Padang pada tahun 2017 - 2019.

\section{Metode}

Jenis penelitian yang dilakukan adalah penelitian deskriptif untuk mengetahui karateristik penyakit endometriosis di RSUP Dr. M. Djamil Padang. Penelitian dilakukan pada bulan Februari - Maret 2020.

Populasi penelitian ini adalah seluruh pasien endometriosis di RSUP Dr. M. Djamil Padang pada tahun 2017-2019 yang berjumlah 195 orang, Sampel penelitian yang dipilih adalah bagian dari populasi yang memenuhi kriteria inklusi dan tidak memiliki kriteria eksklusi dengan menggunakan teknik total sampling sehingga didapatkan sampel sebanyak 98 orang.

Data didapatkan dengan cara observasi rekam medis dan wawancara pasien yang telah memberikan persetujuan dengan informed consent. Analisis yang dilakukan adalah analisis univariat untuk melihat distribusi frekuensi masing-masing variabel. Penelitian ini telah lulus kaji etik oleh Komite Etik Penelitian Kesehatan RSUP Dr. M. Djamil Padang dengan nomor surat 36/KEPK/2020. 


\section{Hasil}

Penelitian ini dilakukan di Instalasi Rekam Medis RSUP Dr. M. Djamil Padang. Pengambilan data didapatkan secara sekunder yaitu dari rekam medis dan secara primer dengan mewawancarai pasien endometriosis yang telah didiagnosis dan dilakukan tindakan oleh dokter spesialis obstetri dan ginekologi. Berdasarkan penelitian yang telah dilakukan pada 98 orang sampel didapatkan gambaran karakteristik endometriosis sebagai berikut.

Table 1. Karakteristik Endometriosis di RSUP Dr. M. Djamil Padang Periode 2017-2019

\begin{tabular}{|c|c|c|c|}
\hline \multicolumn{2}{|r|}{ Variabel } & f & $\%$ \\
\hline \multicolumn{4}{|l|}{ Usia } \\
\hline \multicolumn{2}{|c|}{ Usia Reproduktif (15-44 Tahun) } & 84 & 85,7 \\
\hline \multicolumn{2}{|c|}{ Usia Perimenopause (45-54 Tahun) } & 14 & 14,3 \\
\hline \multicolumn{4}{|c|}{ Keluhan Utama } \\
\hline \multicolumn{2}{|c|}{ Dismenorea } & 68 & 69,4 \\
\hline \multicolumn{2}{|c|}{ Perdarahan per Vaginam (PPV) } & 11 & 11,2 \\
\hline \multicolumn{2}{|c|}{ Haid Lama } & 1 & 1,0 \\
\hline \multicolumn{2}{|c|}{ Haid Banyak Dan Lama } & 1 & 1,0 \\
\hline \multicolumn{2}{|c|}{ Nyeri Panggul } & 3 & 3,1 \\
\hline \multicolumn{2}{|c|}{ Perut Membengkak Dan Nyeri } & 3 & 3,1 \\
\hline \multicolumn{2}{|c|}{ Asimptomatik } & 4 & 4,1 \\
\hline \multicolumn{2}{|c|}{ Perut Membengkak } & 7 & 7,1 \\
\hline \multicolumn{4}{|l|}{ Paritas } \\
\hline \multicolumn{2}{|c|}{ Nullipara } & 59 & 60,2 \\
\hline \multicolumn{2}{|c|}{ Primipara } & 21 & 21,4 \\
\hline \multicolumn{2}{|c|}{ Multipara } & 18 & 18,4 \\
\hline \multicolumn{4}{|l|}{ IMT } \\
\hline \multicolumn{2}{|c|}{ Berat Badan Kurang } & 11 & 11,2 \\
\hline \multicolumn{2}{|c|}{ Berat Badan Normal } & 35 & 35,7 \\
\hline \multicolumn{2}{|c|}{ Overweight at Risk } & 19 & 19,4 \\
\hline \multicolumn{2}{|c|}{ Obesitas Kelas I } & 23 & 23,5 \\
\hline \multicolumn{2}{|c|}{ Obesitaskelas II } & 10 & 10,2 \\
\hline \multicolumn{4}{|c|}{ Stadium Endometriosis } \\
\hline \multicolumn{2}{|c|}{ Stadium I-II (Minimal-Ringan) } & 4 & 4,1 \\
\hline \multicolumn{2}{|c|}{ Stadium III-IV (Sedang-Berat) } & 81 & 82,7 \\
\hline \multicolumn{2}{|c|}{ Adenomiosis } & 13 & 13,3 \\
\hline \multicolumn{4}{|c|}{ Lokasi Anatomis } \\
\hline \multicolumn{4}{|c|}{ Ovarium } \\
\hline \multirow{3}{*}{ Interna } & Uterus & 51 & 52,0 \\
\hline & Tuba Fallopi & 3 & 3,1 \\
\hline & Adnexa & 3 & 3,1 \\
\hline
\end{tabular}

\begin{tabular}{|c|c|c|c|}
\hline & Variabel & f & $\%$ \\
\hline & Gastrointestinal & 7 & 7,1 \\
\hline & Peritoneum & 4 & 4,1 \\
\hline Eksterr & Ligamentum Uterosakral & 1 & 1,0 \\
\hline & Septum Rektovagina & 1 & 1,0 \\
\hline Lama Infe & & & \\
\hline 1-2 Tah & & 11 & 11,2 \\
\hline 3-4 Tal & & 4 & 4,1 \\
\hline$\geq 5$ Tah & & 27 & 27,6 \\
\hline Belum & kah & 15 & 15,3 \\
\hline Sudah & kah $<1$ Tahun & 2 & 2,0 \\
\hline Sudah & kah Dan Memiliki Anak & 39 & 39,8 \\
\hline Terapi Hc & n 3 Bulan Pos Laparoskopi & & \\
\hline Ya & & 74 & 75,5 \\
\hline Tidak & & 24 & 24,5 \\
\hline Perubaha & rajat Nyeri Sesudah Terapi & & \\
\hline Berkur & & 82 & 83,7 \\
\hline Berkur & alu Muncul Lagi & 7 & 7,1 \\
\hline Tidak B & rang & 4 & 4,1 \\
\hline Tidak $A$ & ejala Nyeri Sebelumnya & 5 & 5,1 \\
\hline Ikut Serta & m Program Kehamilan & & \\
\hline & 5 & 5 & 5,1 \\
\hline Ya & 1 & 1 & 1,0 \\
\hline & 1 & 1 & 1,0 \\
\hline Tidak & 89 & 89 & 90,8 \\
\hline & 2 & 2 & 2,0 \\
\hline Kekambu & Penyakit & & \\
\hline Ya & & 11 & 11,2 \\
\hline Tidak & & 87 & 88,8 \\
\hline
\end{tabular}

Berdasarkan Tabel 1, didapatkan pasien yang berusia reproduktif lebih banyak dari usia perimenopause yaitu 84 orang $(85,7 \%)$, keluhan utama yang paling banyak dirasakan pasien saat berobat adalah dismenorea $(69,4 \%)$ dan PPV $(11,2 \%)$, status paritas pasien didapatkan paling banyak adalah nullipara $(60,2 \%)$ diikuti dengan primipara $(21,4 \%)$. Kategori IMT subjek paling banyak didapatkan pada berat badan normal $(35,7 \%)$ dan obesitas kelas I $(23,5 \%)$, stadium endometriosis yang paling banyak ditemukan adalah stadium III-IV (82,7\%), dan lokasi anatomis lesi endometriosis ditemukan paling banyak pada internal panggul terutama pada ovarium (73,5\%). Pasien yang mengalami infertilitas didapatkan sebanyak 42 orang dan kebanyakan mengalami lama infertilitas $\geq 5$ tahun 
$(27,6 \%)$, mayoritas pasien juga diberikan terapi hormon berupa GnRH agonis setelah prosedur laparaskopi $(75,5 \%)$, selain itu mayoritas pasien juga mengalami perbaikan rasa nyeri sesudah terapi $(83,7 \%)$, dan hanya 7 orang pasien $(7,1 \%)$ yang mengikuti program kehamilan setelah terapi, serta hanya $11,2 \%$ pasien yang mengalami kekambuhan.

\section{Pembahasan}

Endometriosis lebih banyak terjadi pada wanita usia reproduktif. Tingginya angka kejadian endometriosis pada wanita usia reproduktif didukung oleh teori pembentukan lesi itu sendiri. Teori menstruasi retrograde dan implantasi menjelaskan bahwa aliran darah mentruasi dapat mengalir balik ke dalam rongga peritoneum, meskipun menstruasi retrograde terjadi pada $90 \%$ wanita, apabila terdapat jaringan endometrium eutopik yang aktif, dan di dukung dengan kelainan fungsi imun tubuh, serta kelebihan estrogen akan mengakibatkan sel bisa bertahan hidup dan menempel pada dinding peritoneum sehingga berkembang menjadi implan endometriosis. ${ }^{6}$ Hal ini didukung oleh penelitian yang dilakukan di RSUD Dr. Moewardi Surakarta oleh Mukti (2012) dengan pasien rentang usia 1545 tahun sebagai mayoritas penderita endometriosis yaitu sebanyak 48 orang $(85,70 \%){ }^{7}$

Dismenorea dan bentuk nyeri lainnya seperti nyeri panggul, nyeri berkemih, dan nyeri ketika buang air besar adalah gejala klasik dari endometriosis. Nyeri yang disebabkan oleh endometriosis adalah nyeri yang dipicu akibat perubahan cairan peritoneal yang mengaktivasi atau mensensitisasi saraf perifer. Proses neuroangiogenesis yang banyak menyelubungi implan endometriosis dapat berkontribusi pada timbulnya rasa nyeri, saraf dikotomi (satu saraf yang berinervasi pada dua jaringan berbeda) juga dapat menyebabkan rasa nyeri di organ yang berbeda dalam pelvik secara bersamaan seperti gangguan gastrointestinal dan urinarius. Nyeri juga dapat memodifikasi struktur saraf pusat dan mengakibatkan sensitisasi sentral sehingga nyeri akan bersifat terus menerus dan kadang akan tetap ada meskipun sudah diobati. ${ }^{8}$

Banyak studi kasus dan epidemiologi yang mendapatkan bahwa peningkatan paritas diasosiasikan dengan penurunan resiko endometriosis. Hal ini terjadi karena kehamilan dapat mengurangi lama waktu wanita terekspos dengan cairan menstruasi, dilatasi permanen yang terjadi karena melahirkan pervaginam juga mengurangi kemungkinan aliran balik menstruasi, serta reaksi desidua akibat tingginya level hormon saat kehamilan juga menurunkan perlengketan dan pertumbuhan implan endometriosis di permukaan pelvik maupun ovarium. ${ }^{4}$ Penelitian oleh Lubis (2017) juga mendapatkan mayoritas pasien endometriosis di RSUP Haji Adam Malik Medan adalah nullipara sebanyak 30 orang $(50,8 \%){ }^{9}$

Kategori IMT berat badan normal yang lebih banyak didapatkan tidak sesuai dengan teori yang menyatakan bahwa penderita endometriosis cenderung memiliki IMT lebih rendah dan jarang mengalami obesitas dibanding populasi kontrol, namun hubungan terbalik endometriosis dengan IMT ini kemungkinan lemah dan memiliki potensi bias karena diagnosis yang lebih sulit pada wanita kelebihan berat badan, kenaikan berat badan akibat kehamilan, dan kehilangan nafsu makan akibat gejala penyakit. ${ }^{10}$ Perbedaan ini dapat dijelaskan karena estradiol (bentuk poten dari estrogen) dan progesteron adalah regulator utama jaringan endometrium, pada penderita endometriosis terdapat kelimpahan dari estrogen ini. Estradiol dihasilkan di tiga tempat pada tubuh dan enzim aromatase berperan penting dalam produksinya, tempat pertama adalah ovarium, kedua jaringan perifer seperti jaringan lemak, kulit, otot, dan tulang, selanjutnya tempat ketiga ialah implant endometriosis itu sendiri. Jaringan perifer tidak menghasilkan estradiol secara langsung dan memerlukan proses konversi, namun tingginya jumlah jaringan perifer tersebut pada tubuh seperti pada wanita dengan kelebihan berat badan dapat menyumbang cukup banyak pada kadar total estradiol di darah. ${ }^{11}$

Tingginya ditemukan stadium III-IV dapat disebabkan oleh keterbatasan seperti pemeriksaan fisik yang tidak dapat dilakukan pada wanita yang belum aktif secara seksual dapat menunda identifikasi endometriosis stadium awal yang masih superfisial. Kebiasaan pasien untuk mengabaikan gejala serta salah diagnosis juga berkontribusi dalam penundaan diagnosis endometriosis selama bertahun-tahun, akibatnya gejala menetap dan sudah berdampak buruk pada kualitas hidup pasien, hingga dapat terjadi 
sensitisasi sentral. Salah diagnosis dan pengobatan endometriosis yang tidak adekuat dapat membantu peningkatan keparahan penyakit hingga menyebabkan gangguan fertilitas, sensitisasi sentral, hingga nyeri panggul kronik. Selain itu banyak studi yang telah membuktikan tidak ada kolerasi antara tingkat keparahan penyakit dengan lokasi maupun keparahan gejala, sehingga bisa ada pasien yang asimtomatik dan ditemukan stadium keparahan penyakitnya sudah tinggi. ${ }^{12,13}$

Lokasi ditemukannya lesi endometriosis pada pasien bisa terdapat dibeberapa tempat, karena kebanyakan pasien bisa menderita endometriosis multipel yang artinya ditemukan implan yang tersebar di beberapa lokasi anatomis panggul secara bersamaan. Tigginya angka pembentukan implan endometriosis di internal pelvik dapat terjadi karena berat dan lamanya eksposur terhadap retrograde menstruation, namun tidak menutup kemungkinan terbentuknya implan dengan cara lain seperti coelomic metaplasia, maupun lewat penyebaran darah atau limfe. Pembentukan implan endometriosis yang ditemukan di lokasi ekstra pelvik dapat terjadi karena penyebaran sel endometrium aktif lewat pembuluh darah atau limfe sehingga bisa ditemukan di lokasi ginekologi seperti vulva, vagina, dan servik, dan atau non ginekologi seperti usus,appendiks, paru, dan kulit. ${ }^{14}$

Tingginya angka infertilitas pada pasien endometriosis menjelaskan bahwa penyakit ini berpengaruh signifikan dalam mengganggu tingkat reproduksi penderitanya. Infertilitas diartikan sebagai ketidakmampuan pasangan untuk mendapatkan kehamilan setelah 1 tahun lamanya melakukan hubungan seksual yang reguler dan tidak menggunakan kontrasepsi. Menurut penelitian Moini et al. (2013) lamanya infertilitas dapat digunakan sebagai faktor prediksi tingkat keparahan endometriosis. Tingkat kesuburan rata-rata tiap bulannya pada wanita dengan endometriosis cenderung lebih rendah dari pada wanita normal, sehingga endometriosis diasosiasikan dengan angka kelahiran yang lebih rendah. Durasi infertilitas memiliki efek berkebalikan dengan kemungkinan mendapatkan kehamilan.15,16
Tujuan pemberian terapi hormonal posoperatif adalah untuk menurunkan kemungkinan kekambuhan, dengan memperhatikan kemungkinan implan endometriosis yang tidak terbuang saat laparoskopi, selain itu lesi dapat muncul dalam bentuk mikroskopik sehingga tidak tampak saat operasi. Kekambuhan endometriosis dapat berasal dari pertumbuhan sisa lesi yang luput saat operasi maupun sisa sel yang tidak habis terbuang. Karena hal itu, maka diberikan terapi hormonal pos-operasi jangka pendek (3-6 bulan) berupa GnRH agonis untuk menambah efektivitas dan mengurangi kekambuhan, tetapi ada kemungkinan lain kekambuhan karena endometriosis tidak hanya tumbuh kembali dari sisa sel tapi juga bisa tumbuh lagi dari sel baru, sehingga praktik ini masih banyak diperdebatkan akan efektivitasnya namun kenyataannya masih di lakukan secara luas untuk menstrerilisasi sisa-sisa sel lesi endometriosis yang tidak teridentifikasi atau tidak bisa di eksisi saat operasi sehingga memperpanjang free interval dari nyeri dan kekambuhan pasca pembedahan. ${ }^{17}$

Alasan pasien tidak mengikuti program kehamilan didapatkan beragam, seperti tidak adanya biaya, ingin mendapatkan anak secara alami, dan sudah tidak lagi memiliki keinginan untuk mendapatkan keturunan. Selain itu, ada pasien yang memang tidak bisa mengikuti program kehamilan karena sudah menjalani prosedur histerektomi. Persentase kehamilan setelah dilakukan prosedur pembedahan adalah $41 \%$ dan menurun hingga $26 \%$ setelah dilakukan pembedahan berulang. Hal ini terjadi karena berkurangnya cadangan ovarium dan jaringan ovarium fungsional sebagai efek dari pembedahan. Keberhasilan teknologi reproduksi berbantu tergantung pada, usia penderita, lama infertilitas, stadium keparahan penyakit, distorsi organ genitalia, terapi sebelumnya, dan lain lain. Keberhasilan terapi pembedahan dalam menyembuhankan infertilitas tergantung dengan tingkat keparahan penyakit, dimana stadium yang lebih tinggi maka tingkat kehamilan juga makin rendah. ${ }^{5}$

Kehamilan pada wanita dengan endometriosis juga lebih beresiko dan dihubungkan dengan komplikasi seperti kehamilan ektopik, abortus, kelahiran prematur, perdarahan antepartum, dan preeklampsia. ${ }^{18}$ 
Banyak studi yang mendapatkan terjadi perbaikan yang signifikan pada nyeri, dismenorea, dan gejala lainnya setelah dilakukan terapi pembedahan, namun banyaknya perlengketan, pembedahan endometeriosis berulang, dan penggunaan obat stimulan ovulasi menjadi faktor yang tidak mendukung peningkatan prognosis. Kehamilan yang didapatkan setelah terapi pembedahan memperlihatkan efek protektif terhadap kekambuhan rasa nyeri dan kista endometriosis. ${ }^{19}$

Meskipun pembedahan memberikan hasil yang memuaskan, masih ada kemungkinan kekambuhan penyakit dan gejala setelah itu, namun munculnya gejala tidak selalu menandakan kekambuhan penyakit. Karena itu terapi medikamentosa setelah operasi bersifat krusial untuk membatasi kemungkinan kambuh. ${ }^{13}$ Menurut Vercellini apabila terapi pembedahan tidak diikuti dengan terapi adjuvan berupa medikamentosa maka angka kekambuhan gejala dan penyakit menjadi tinggi hingga $50 \%$ pada follow up setelah 5 tahun. Pembedahan ulang harus dipertimbangkan dengan baik karena dapat berdapat merugikan terhadap fertilitas pasien, apabila memiliki anak bukan merupakan prioritas lagi, maka terapi definitif seperti histerektomi bisa dilakukan. ${ }^{20}$

\section{Simpulan}

Berdasarkan penelitian yang telah dilakukan, maka dapat disimpulkan bahwa mayoritas pasien berusia reproduktif (15-45 tahun), mengeluhkan dismenorea, belum pernah melahirkan (nullipara), dengan kategori IMT berat badan normal. Stadium III-IV adalahs stadium penyakit paling banyak ditemukan dan pada lokasi anatomis internal panggul. Pasien yang mengalami infertilitas kebanyakan dengan durasi lebih dari 5 tahun, selain itu mayoritas pasien diberikan terapi hormon pos laparoskopi, merasakan perbaikan rasa nyeri, tidak mengikuti program kehamilan dan tidak mengalami kekambuhan setelah terapi.

\section{Daftar Pustaka}

1. Nnoaham KE, Hummelshoj L, Webster P, D'Hooghe T, Nardone FC, Nardone CC, et al. Impact of endometriosis on quality of life and work productivity: a multicenter study across ten countries. Fertility and Sterility. 2011; 96: 366-73.
2. DiVasta AD, Vitonis AF, Laufer MR, Missmer SA. Spectrum of symptoms in women diagnosed with endometriosis during adolescence vs adulthood. American Journal of Obstetrics and Gynecology. 2018; 218: 324.

3. Hidayat A, Hendry D. Karakteristik penderita endometriosis dan adenomiosis di RSUP Dr. M. Djamil padang periode januari 2017-oktober 2018. Andalas Obstetrics and Gynecology Journal. 2019; 3: 28-41.

4. D'Hooghe T. Endometriosis. Di: Berek JS, editor. Berek \& Novak's Gynecology. 15th ed. Philadephia: Lippincott William \& Wilkins; 2012. p. 505-56.

5. Leyland $N$, Casper $R$, Laberge $P$, Singh SS. Endometriosis: diagnosis and management. Journal of Endometriosis. 2010; 2: 107-34.

6. Giudice LC, Burney RO, Becker C, Missmer S, Montgomery G, Rogers PAW, et al. Genetics and genomics of endometriosis. Di: Leung P, Qiao J, editor. Human reproductive and prenatal genetics. 1st ed. Massachusetts: Academic Press; 2019. p. 399426.

7. Mukti P. Faktor resiko kejadian endometriosis. Unnes Journal of Public Health. 2014; 3: 1-10.

8. Morotti M, Vincent K, Becker CM. Mechanisms of pain in endometriosis. European Journal of Obstetrics \& Gynecology and Reproductive Biology. 2017; 209: 8-13.

9. Khairina N. Karakteristik pasien endometriosis di RSUP Haji Adam Malik Medan tahun 2016 (skripsi). Medan: Fakultas Kedokteran Universitas Sumatera Utara; 2017.

10. Parazzini F, Esposito G, Tozzi L, Noli S, Bianchi S. Epidemiology of endometriosis and its comorbidities. European Journal Obstetrics \& Gynecology Reproductive Biology. 2016; 209: 3-7.

11. Bulun SE, Monsavais D, Pavone ME, Dyson M, Xue Q, Attar E, et al. Role of estrogen receptor- $\beta$ in endometriosis. Semin Reprod Med. 2012; 30; 39-45.

12. Agarwal SK, Chapron C, Giudice LC, Laufer MD, Leyland M, Missmer SA, et al. Clinical diagnosis of endometriosis : a call to action. American Journal of Obstetric \& Gynecology. 2019; 220: 354.

13. Zondervan KT, Becker CM, Koga K, Missmer SA, Taylor RN, Vigan P. Endometriosis. Nature Reviews Disease Primer. 2018; 4: 1-12.

14. Lee HJ, Park YM, Jee BC, Kim YB, Suh CS. Various anatomic locations of surgically proven endometriosis: A single-center experience. Obstetrics \& Gynecology Science. 2015; 58: 53-8.

15. Moini A, Malekzadeh F, Amirchaghmaghi E, Kashfi F, Akhoond MR, Saei M, et al. Risk factors associated with endometriosis among infertile Iranian women. Arch Med Sci. 2013; 9: 506-14.

16. Bulletti C, Coccia ME, Battistoni S, Borini A. Endometriosis and infertility. J Assist Reprod Genet. 2010; 27: 441-7.

17. Somigliana E, Vercellini P, Vigano P, Benaglia L, Busnelli A, Fedele L. Postoperative medical therapy after surgical treatment of endometriosis: from adjuvant therapy to tertiary prevention. JMIG. 2014; 21: 328-34.

18. Brosens I, Brosens JJ, Fusi L, Al-Sabbagh M, Kuroda K, Benagiano G. Risks of adverse pregnancy outcome in endometriosis. Fertility and Sterility. 2012; 98: 30-5.

19. Porpora MG, Pallante D, Ferro A, Crisafi B, Bellati F, Panici PB. Pain and ovarian endometrioma recurrence after laparoscopic treatment of 
endometriosis: a long-term prospective study. Fertility and Sterility. 2010; 93: 716-21.

20. Vercellini P, Viganò P, Somigliana E, Fedele L. Endometriosis : pathogenesis and treatment. Nature Reviews Endocrinology. 2014; 10: 261-75 